\title{
PERFORMING PUMPING TEST DATA ANALYSIS APPLYING COOPER-JACOB'S METHOD FOR ESTIMATING OF THE AQUIFER PARAMETERS
}

DANA KHIDER MAWLOOD - Assist. Prof. PhD, Civil Engineering Department, College of Engineering, University of Salahaddin, Erbil, Kurdistan Region of Iraq, e-mail: dana.mawlood@su.edu.krd

JWAN SABAH MUSTAFA - Engineer, General Directorate of Dams and Reservoirs, Ministry of agricultural and water resources, Erbil, Kurdistan Region of Iraq, e-mail: jwan.mustafa1@su.edu.krd

\begin{abstract}
Single well test is more common than aquifer test with having observation well, since the advantage of single well test is that the pumping test can be conducted on the production well with the absence of observation well. A kind of single well test,which is step-drawdown test used to determine the efficiency and specific capacity of the well, however in case of single well test it is possible to estimate Transmissivity, but the other parameter which is Storativity is overestimated, so the aim of this study is to analyze four pumping test data located in KAWRGOSK area by using cooper-Jacob's(1946) time drawdown approximation of Theis method to estimate the aquifer parameters, also in order to determine the reasons which are affecting the reliability of the Storativity value and obtain the important aspect behind that in practice.
\end{abstract}

Keywords: aquifer parameters, single well test, Cooper-Jacob's straight line method

\section{Introduction}

The most important method to estimate the aquifer parameters are testing with having observation well, but it's cost more than conducting pumping test without observation well which is called single well test, so that since the last decade there are many experiences that are tried to discover a method to estimate the aquifer parameters through analyze single well test data such as (choi,Byung-soo,2007)which tried to find out the Storativity by determining skin factor and effective wellbore storage, and the method of (P. N. Ballukraya, et al,1991) it derived an equation to estimate Storativity by recovery test, Also (M. Razack, et al, 1991) tried to determine Transmissivity through specific capacity data, then (Keith J. Halford, et al,2006) attempt to obtain Transmissivity from single test data, so the articles related to the study area locations are including (Imad Al-Din Omer Hassan,1998),(Mariwan Akram Hama Saeed Chnaray,2003), (Dara Faeq Hamamin,2004),(Salahaddin Saeed Ali,2007),(Diary Ali Mohammad Ameen AlManmi,2008),(Shwan Omer Ismail Shwani,2008), Also (Masoud Hussein Hamed,2013). There are many papers and references that ordered to the Storativity value in case of the absence of observation well is not accurate,because it depends mainly on the radial distances between pumping well to point of measuring drawdown from those(G.P. Kruseman, et al,1991),(Yaran M.Sternberg,1970),(J. Boonstra, et al, 2001),(Michael Kasenow,2006), and(Neven. Kresic,2006).

Single well aquifer testing can provide the value of Transmissivity,whereas preclude the cost and access of multi-well aquifer testing, so usually in this case the test data analyzed by CooperJacob's (1946) straight line method due to it's simplicity. Transmissivity is estimated by fitting a straight line between time versus drawdown on semi-logarithmic paper. The test data of both confined and unconfined aquifers were analyzed by many practitioners that are used cooperJacob method to estimate the drawdown equation, regardless of the differences between theoretical and practical conditions. Whereas the Cooper-Jacob's(1946) method simplified the Theis(1935) equations, which was derived under the following assumptions: the pumped well should be fully penetrate, confined aquifer, homogeneous and isotropic[8]. 
Normally to analyze pumping test data it needed to obtain field data, that means drawdown and flow rate as a function of time, to simulate this data it should take the conditions that for constant pumping rate at the well and the other for the constant head at the well.

Theis(1935)assumed that the pumping rate is constant in a confined, homogeneous, isotropic, infinite areal extent and transient flow without recharge is:

$$
\nabla^{2} h=\frac{s}{K b} \cdot \frac{\partial h}{\partial t}
$$

using boundary condition of the well:

$$
\begin{aligned}
& \mathrm{Q}=\mathrm{q} . \mathrm{A} \\
& q=\frac{Q_{\text {well }}}{2 \pi r b} \\
& \mathrm{~h}=\mathrm{h}_{\text {initial, }} @ \mathrm{r}=\mathrm{r}_{\mathrm{w}}, \\
& @ \mathrm{r}=\mathrm{r} \infty
\end{aligned}
$$

so Theis(1935) solution:

$$
\begin{aligned}
& s=\frac{Q}{4 \pi K b} \int_{u}^{\infty} \frac{e^{-u}}{u} \cdot d u, \int_{u}^{\infty} \frac{e^{-u}}{u} \cdot d u=W(u)=\text { well function } \\
& W(u)=\left[\gamma-\ln u+u-\frac{u}{2.2 !}+\frac{u}{3.3 !}-\cdots\right], \gamma=\text { Euler number }=-0.5772 \\
& u=\frac{r^{2} s}{4 T t}
\end{aligned}
$$

or:

$$
s=\frac{Q}{4 \pi T} W(u \text {, Theis equation for drawdown) }
$$

The above equation is known as Theis matching curve by plotting field data obtained during pumping test on type curve using the same scale on semi-logarithmic paper, then the two curves superimposed on each other the unknown values can be obtained to calculate the aquifer parameters. Later Cooper-Jacob suggested that Theis(1935) method can be simplified if Time is long and $r$ is small,then $u$ should be small or equal than 0.01 , thus the only two first terms can be taken into account.

and also he supposed that the equation also can be used for water-table type aquifer if $2 s<<b$, which is the aquifer thickness, so that the presented study preferred to select this method for analyzing the test results, and recommend the reasons behind that carefully.

\section{Cooper-Jacob's time drawdown method}

Cooper and Jacob(1946) simplified Theis(1935) equation, who noted that for large values of time $t$, and small value of $r,(u \leq 0.01)$, the series expansion of the Theis (1935) equation after the first two terms become negligible[17], so that:

Theis(1935) drawdown equation:

where:

$$
s=\frac{Q}{4 \pi T}\left[-0.5772-\ln u+u-\frac{u}{2.2 !}+\frac{u}{3.3 !}-\cdots\right]
$$

$$
u=\frac{r^{2} s}{4 T t}
$$

According to Jacob's (1946) assumptions the drawdown equation simplified to:

$$
s=\frac{Q}{4 \pi T}[-0.5772-\ln u]
$$

Then rearranging the equation and changing -0.5772 to $\ln 1.78$ :

$$
s=\frac{Q}{4 \pi T}\left[-\ln 1.78-\ln \frac{r^{2} s}{4 T t}\right]
$$




$$
\begin{aligned}
& s=\frac{Q}{4 \pi T}\left[-\left(\ln 1.78+\ln \frac{r^{2} S}{4 T t}\right)\right] \\
& s=\frac{Q}{4 \pi T}\left[-\ln \frac{1.78 r^{2} S}{4 T t}\right]
\end{aligned}
$$

inverse the term using Ln rules to get:

$$
S=\frac{Q}{4 \pi T} \ln \left[\frac{4 T t}{1.78 r^{2} S}\right]
$$

For a small value of $r$, the eq.(7) is the equation of a straight line plotted between drawdown(s) and log of time(t) on semi-log paper, and rewriting the equation in the form of logarithmic,it become:

$$
s=\frac{2.3 \mathrm{Q}}{4 \pi \mathrm{T}} \log \left[\frac{2.25 T t}{r^{2} S}\right]
$$

thus, the straight line equation is:

$$
\begin{gathered}
S=\frac{2.3 Q}{4 \pi T} \log \left[\frac{2.25 T}{r^{2} S}\right]+\frac{2.3 Q}{4 \pi T} \log t \\
Y=B \text { (intercept) } \quad+A(\text { slope }) x
\end{gathered}
$$

The plot of $\mathrm{s}$ against Logt should be a straight line, the extend of the straight line at zero drawdwon, $t=t_{o}$, so that:

$$
\frac{2.25 T t_{\mathrm{o}}}{r^{2} S}=1
$$

or:

$$
S=\frac{2.25 T t_{0}}{r^{2}}
$$

and:

$$
\Delta \mathrm{s}=\frac{2.3 \mathrm{Q}}{4 \pi \mathrm{T}}
$$

then Transmissivity is:

Where:

$$
T=\frac{2.3 Q}{4 \pi \Delta s}
$$

$s$ - is drawdown $[m]$

$Q$ - is constant rate pumping test $\left[\mathrm{m}^{3} \cdot \mathrm{min}^{-1}\right]$

$T$ - is Transmissivity $\left[\mathrm{m}^{2} \cdot \mathrm{min}^{-1}\right]$

$S$ - is Storativity [unit less]

$r$ - is radial distance $[m]$

$r_{w}$ - is well radius $[m]$, see Figure 1

$u$ - is well constant

$W(u)$ - is well function

$t$ - is time of pumping [ $\mathrm{min}$ ]

$\Delta s$ - is slope of the line per one log cycle $[m]$

$t_{o}$ - is the initial time of pumping test at zero drawdown [ $\left.\mathrm{min}\right]$

$\gamma$ - is Euler number $=-0.5772$

$h$ - is aquifer thicknessin water-table aquifer $[m]$

$b$ - is the aquifer thickness in case confined $[m]$

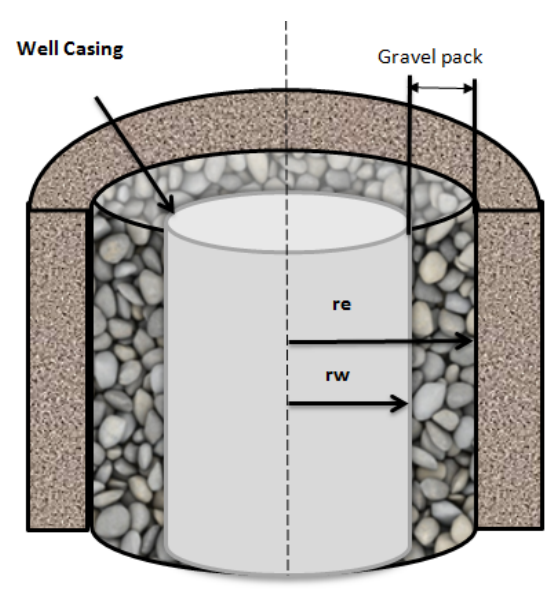

Fig. 1 - Section of the well

\subsection{Study area location}

The study area is KAWRGOSK, which is located at a distance of about $25 \mathrm{~km}$ from center of Erbil city,Kurdistan Region of Iraq and the Area is about $108.379 \mathrm{~km}^{2}$,the geological formation 
of the location is Bakhtiari formation,see Figure in Appendix. The map shown the position of the wells through GIS program (ArcMap10) with the following UTM coordinate system, see Figure2:
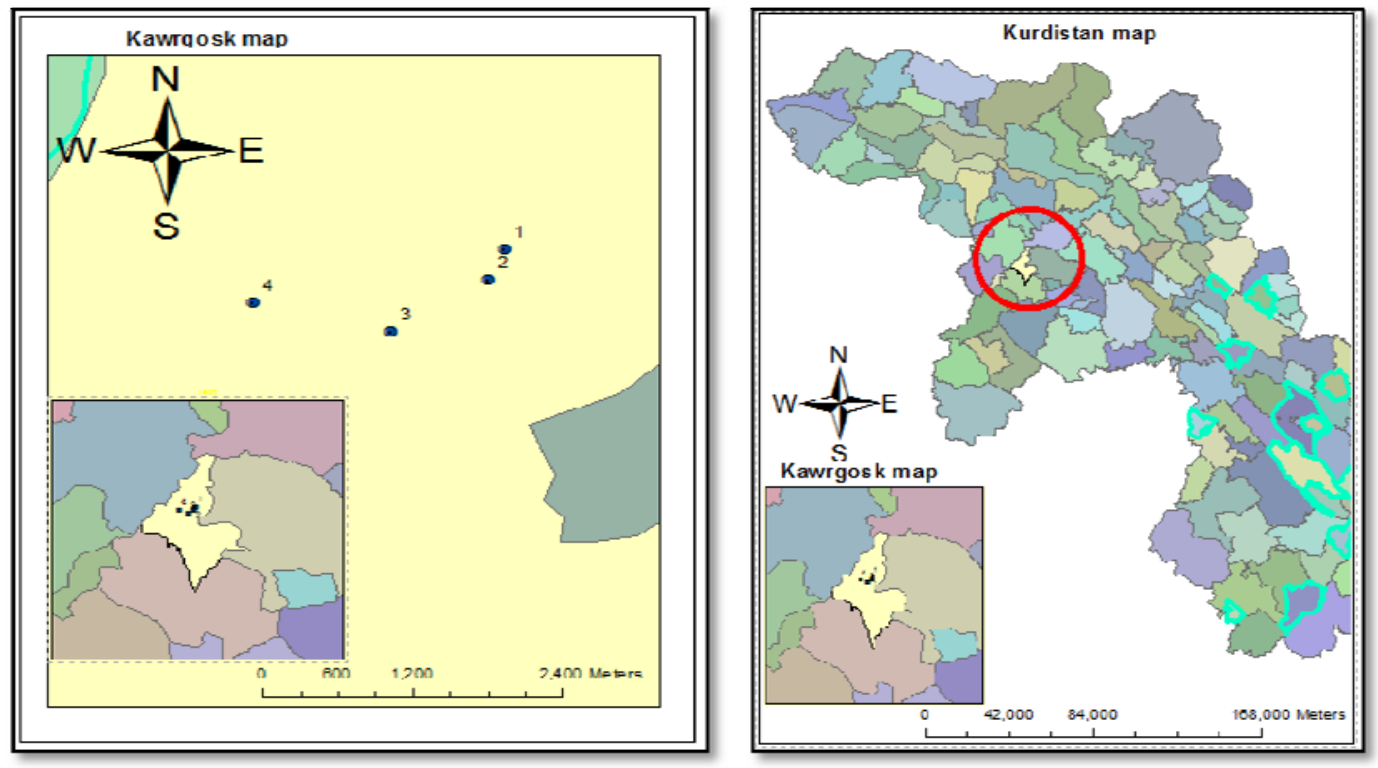

Fig. 2 - Wells location in KAWRGOSK.

and the coordinate of the well location is presented in the Table 1:

Table 1

\section{Coordinate of well location in KAWRGOSK}

\begin{tabular}{|c|c|c|c|}
\hline $\begin{array}{c}\text { Well } \\
\text { Description }\end{array}$ & $\begin{array}{c}\text { E } \\
\text { (Longitude) } \\
38 \mathrm{~S}\end{array}$ & N(altitude) & Elevation \\
\hline 1 & 0393748 & 4023978 & 338 \\
\hline 2 & 0393619 & 4023685 & 336 \\
\hline 3 & 0392842 & 4023182 & 307 \\
\hline 4 & 0391732 & 4023471 & 303 \\
\hline
\end{tabular}

\subsection{Application of Cooper-Jacob method}

The pumping test results of the wells are plotted on semi-logarithmic paper, the slope of the line $\Delta s$ with initial time of pumping test $\mathrm{t}_{\mathrm{o}}$ were determined, as presented in Figure 3 :

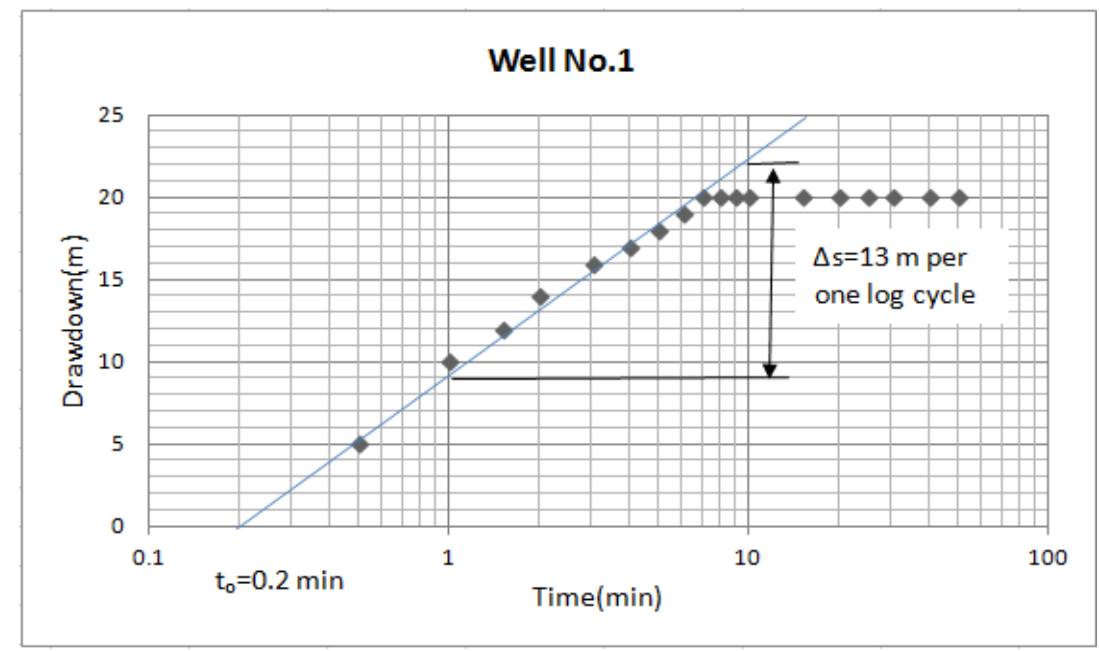

Fig. 3 - Well No.1 time-drawdown straightline plot 
The test data of well No.1 have taken into account, see Table 2:

Pumping test data of well No.1

\begin{tabular}{|c|c|c|}
\hline Well 1 & & \\
\hline Time(min) & $\mathrm{sw}(\mathrm{m})$ & Yield(m³/min) \\
\hline 0 & 0 & 0 \\
\hline 0.5 & 5 & 0.462 \\
\hline 1 & 10 & 0.462 \\
\hline 1.5 & 12 & 0.462 \\
\hline 2 & 14 & 0.462 \\
\hline 3 & 16 & 0.462 \\
\hline 4 & 17 & 0.462 \\
\hline 5 & 18 & 0.462 \\
\hline 6 & 19 & 0.462 \\
\hline 7 & 20 & 0.462 \\
\hline 8 & 20 & 0.462 \\
\hline 9 & 20 & 0.462 \\
\hline 10 & 20 & 0.462 \\
\hline 15 & 20 & 0.462 \\
\hline 20 & 20 & 0.462 \\
\hline 25 & 20 & 0.462 \\
\hline 30 & 20 & 0.462 \\
\hline 40 & 20 & 0.462 \\
\hline 50 & 20 & 0.462 \\
\hline
\end{tabular}

And the detail of the wells are shown in the Table 3:

Table 3

Well informations

\begin{tabular}{|c|c|c|c|c|c|c|}
\hline Well & $\begin{array}{c}\text { Yield } \\
\left(\mathrm{m}^{3} / \mathrm{min}\right)\end{array}$ & $\begin{array}{c}\text { well } \\
\text { radius } \\
(\mathrm{m})\end{array}$ & $\begin{array}{c}\text { Casing } \\
\text { radius } \\
(\mathrm{m})\end{array}$ & $\begin{array}{c}\text { well } \\
\text { Depth(m) }\end{array}$ & $\begin{array}{c}\text { Static water } \\
\text { level(m) }\end{array}$ & $\begin{array}{c}\text { Dynamic water } \\
\text { level(m) }\end{array}$ \\
\hline 1 & 0.462 & 0.11 & 0.156 & 220 & 80 & 100 \\
\hline 2 & 0.568 & 0.11 & 0.156 & 220 & 60 & 92 \\
\hline 3 & 0.435 & 0.11 & 0.156 & 215 & 64 & 76 \\
\hline 4 & 0.371 & 0.11 & 0.156 & 210 & 47 & 90 \\
\hline
\end{tabular}

To estimate the Transmissivity and Storativity for well No. 1 is as follow:

Pumping rate, $Q=0.462 \mathrm{~m}^{3} / \mathrm{min}$ or $\left(0.0077 \mathrm{~m}^{3} / \mathrm{sec}\right)$.

well radius $r_{w}=0.11 \mathrm{~m}$

$\Delta s=13 \mathrm{~m}$, and $t_{o}=0.2 \mathrm{~min}$, see Figure 3;

$$
\begin{aligned}
& \mathrm{T}=\frac{2.3 \mathrm{Q}}{4 \pi \Delta \mathrm{s}}=\frac{2.3(0.462)}{4 * 3.14 * 13}=\frac{0.007 \mathrm{~m}^{2}}{\min } \\
& \mathrm{T}=9.371 \frac{\mathrm{m}^{2}}{\text { day }} \text { or } 0.00012 \mathrm{~m}^{2} / \mathrm{sec}
\end{aligned}
$$

and the Storativity:

$$
S=\frac{2.25 T t_{\mathrm{o}}}{r_{w}{ }^{2}}=\frac{2.25 * 0.007 * 0.2}{0.11^{2}}=0.242
$$


The storage coefficient For unconfined aquifer type should be within 0.1 to 0.3 according to [11].

The pumping test results obtained for the other wells are shown in Tables 4,5,6 respectively.

Table 4

Pumping test data of well No. 2

\begin{tabular}{|c|c|c|}
\hline Well 2 & & \\
\hline Time(min) & $\mathrm{sw}(\mathrm{m})$ & Yield(m³/min) \\
\hline 5 & 5 & 0.568 \\
\hline 10 & 15 & 0.568 \\
\hline 15 & 20 & 0.568 \\
\hline 20 & 22 & 0.568 \\
\hline 25 & 25 & 0.568 \\
\hline 30 & 28 & 0.568 \\
\hline 35 & 30 & 0.568 \\
\hline 40 & 31 & 0.568 \\
\hline 45 & 32 & 0.568 \\
\hline 50 & 32 & 0.568 \\
\hline 55 & 32 & 0.568 \\
\hline 60 & 32 & 0.568 \\
\hline 80 & 32 & 0.568 \\
\hline 100 & 32 & 0.568 \\
\hline 120 & 32 & 0.568 \\
\hline 150 & 32 & 0.568 \\
\hline 180 & 32 & 0.568 \\
\hline 220 & 32 & 0.568 \\
\hline 280 & 32 & 0.568 \\
\hline 300 & 32 & 0.568 \\
\hline 400 & 32 & 0.568 \\
\hline
\end{tabular}

The time versus drawdown plot are illustrate in Figure 4:

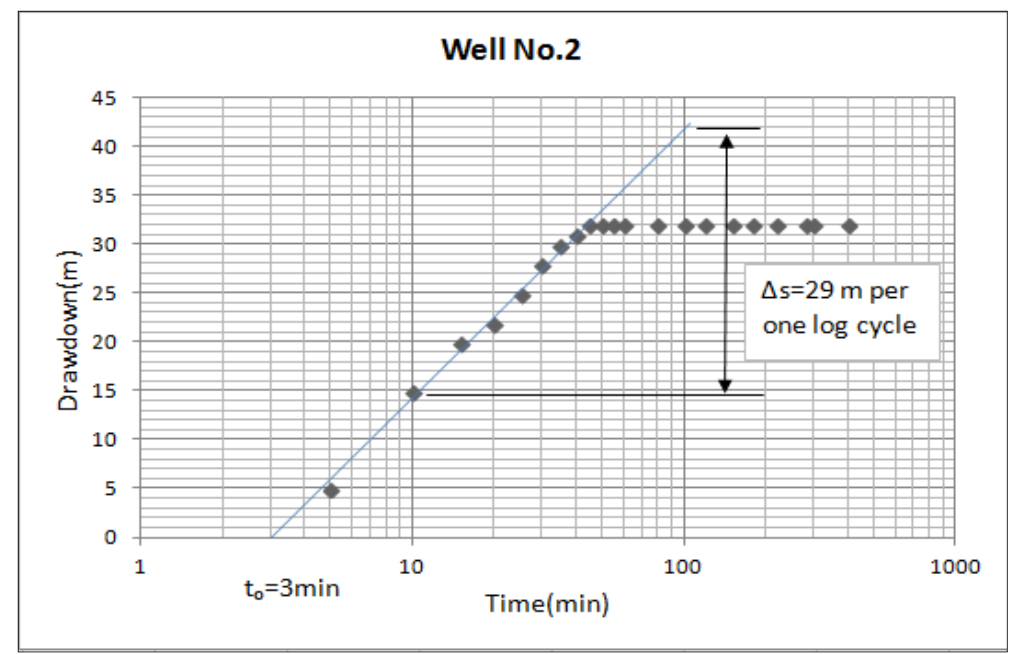

Fig.4 - Well No.2 time-drawdown straightline plot

The test data of well No.3 and the straightline of the time against drawdown in Table 5, and Figure 5 respectively. 
Pumping test data of well No. 3

\begin{tabular}{|c|c|c|}
\hline Well 3 & & \\
\hline Time(min) & $\mathrm{sw}(\mathrm{m})$ & Yield(m³/min) \\
\hline 0 & 0 & 0.435 \\
\hline 0.5 & 0.5 & 0.435 \\
\hline 1 & 1 & 0.435 \\
\hline 1.5 & 1.3 & 0.435 \\
\hline 2 & 1.6 & 0.435 \\
\hline 3 & 2.4 & 0.435 \\
\hline 4 & 3.4 & 0.435 \\
\hline 5 & 4.2 & 0.435 \\
\hline 6 & 4.8 & 0.435 \\
\hline 7 & 5.3 & 0.435 \\
\hline 8 & 5.9 & 0.435 \\
\hline 9 & 6.3 & 0.435 \\
\hline 10 & 6.7 & 0.435 \\
\hline 15 & 8.1 & 0.435 \\
\hline 20 & 9.5 & 0.435 \\
\hline 25 & 10.2 & 0.435 \\
\hline 30 & 10.7 & 0.435 \\
\hline 40 & 11.5 & 0.435 \\
\hline 50 & 11.8 & 0.435 \\
\hline 60 & 12 & 0.435 \\
\hline 80 & 12 & 0.435 \\
\hline 100 & 12 & 0.435 \\
\hline 120 & 12 & 0.435 \\
\hline 140 & 12 & 0.435 \\
\hline 160 & 12 & 0.435 \\
\hline 200 & 12 & 0.435 \\
\hline
\end{tabular}

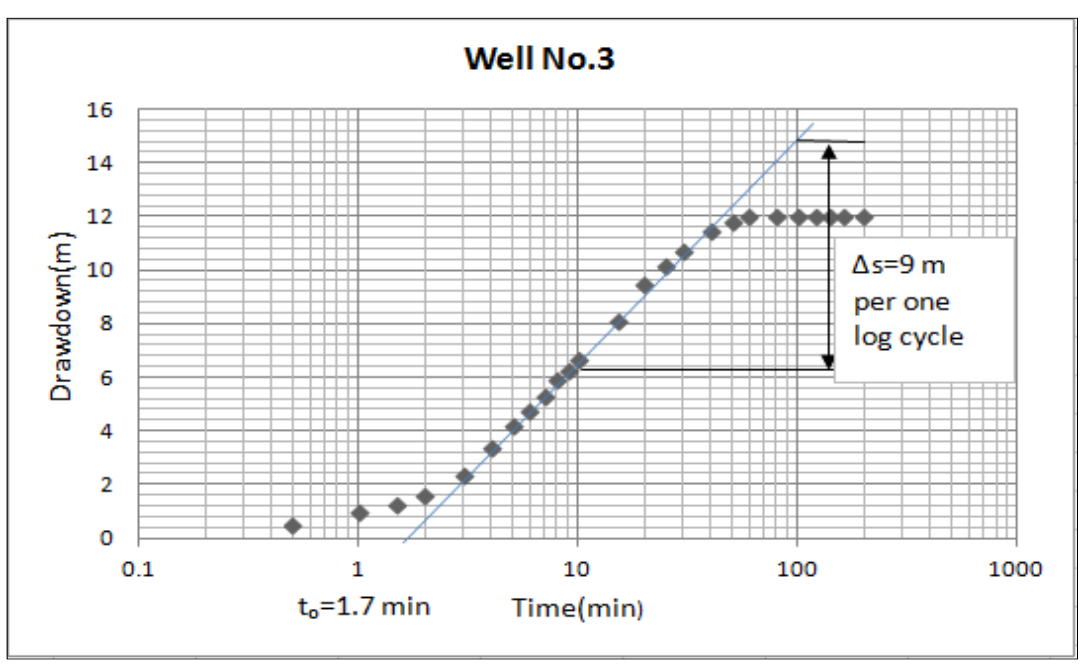

Fig.5 - Well No.3 time - drawdown straightline plot 
The Test data of well No. 4 are presented in Table 6:

Pumping test data of well No. 4

\begin{tabular}{|c|c|c|}
\hline Well 4 & & \\
\hline Time(min) & $\mathrm{sw}(\mathrm{m})$ & Yield(m³/min) \\
\hline 0 & 0 & 0.371 \\
\hline 0.5 & 0.3 & 0.371 \\
\hline 1 & 0.8 & 0.371 \\
\hline 1.5 & 1 & 0.371 \\
\hline 2 & 2 & 0.371 \\
\hline 3 & 4.5 & 0.371 \\
\hline 4 & 7.2 & 0.371 \\
\hline 5 & 9.6 & 0.371 \\
\hline 6 & 11.9 & 0.371 \\
\hline 7 & 13.7 & 0.371 \\
\hline 8 & 15 & 0.371 \\
\hline 9 & 16.8 & 0.371 \\
\hline 10 & 18.1 & 0.371 \\
\hline 15 & 22.4 & 0.371 \\
\hline 20 & 26.4 & 0.371 \\
\hline 25 & 29 & 0.371 \\
\hline 30 & 30.5 & 0.371 \\
\hline 40 & 34 & 0.371 \\
\hline 50 & 36.6 & 0.371 \\
\hline 60 & 38.2 & 0.371 \\
\hline 80 & 41.5 & 0.371 \\
\hline 100 & 43 & 0.371 \\
\hline 120 & 43 & 0.371 \\
\hline
\end{tabular}

The semilogarithmic plot of well No.4 are shown in Figure 6

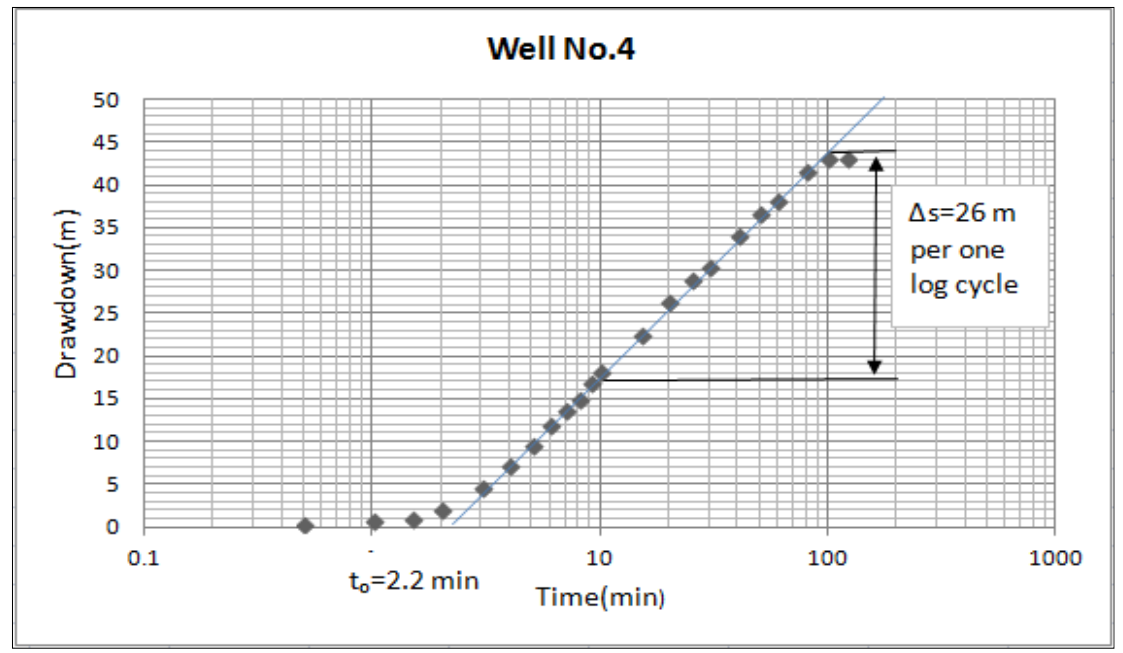

Fig.6 - Well No.4 time - drawdown straightline plot 
The calculation of well data.

\begin{tabular}{|c|c|c|c|c|c|c|c|c|c|}
\hline Well & $\begin{array}{c}\mathbf{Q} \\
\left(\mathbf{m}^{3} / \mathbf{m i n}\right)\end{array}$ & $\begin{array}{c}\mathbf{r}_{\mathbf{w}} \\
(\mathbf{m})\end{array}$ & $\begin{array}{c}\Delta \mathbf{s} \\
\mathbf{( m )}\end{array}$ & $\begin{array}{c}\mathbf{t}_{\mathbf{0}} \\
\mathbf{( m i n )}\end{array}$ & $\begin{array}{c}\mathbf{T} \\
\left(\mathbf{m}^{2} / \mathbf{d a y}\right)\end{array}$ & $\begin{array}{c}\mathbf{T} \\
\left(\mathbf{m}^{2} / \mathbf{d a y}\right)\end{array}$ & class type & $\mathbf{S}$ & $\begin{array}{c}\mathbf{( S )} \\
\text { range }\end{array}$ \\
\hline 1 & 0.462 & 0.11 & 13 & 0.2 & 9.371 & 1 to 10 & Low & 0.242 & $0.1-0.3$ \\
\hline 2 & 0.568 & 0.11 & 29 & 3 & 5.165 & 1 to 10 & Low & 2.001 & $0.1-0.4$ \\
\hline 3 & 0.435 & 0.11 & 9 & 1.7 & 12.745 & 10 to 100 & Intermediate & 2.798 & $0.1-0.5$ \\
\hline 4 & 0.371 & 0.11 & 26 & 2.2 & 3.763 & 1 to 10 & Low & 1.069 & $0.1-0.6$ \\
\hline
\end{tabular}

Classification of the Transmissivity according to [42], see Table 8:

Table 8

Classification of Transmissivity

\begin{tabular}{|c|c|c|}
\hline $\begin{array}{c}\text { Coefficient of } \\
\text { Transmissivity } \\
\text { (m²/day) }\end{array}$ & $\begin{array}{c}\text { class of } \\
\text { Transmissivity } \\
\text { magnitude }\end{array}$ & $\begin{array}{c}\text { Designation of } \\
\text { Transmissivity } \\
\text { magnitude }\end{array}$ \\
\hline$>1000$ & I & very high \\
\hline 100 to1000 & II & High \\
\hline 10 to 100 & III & Intermediate \\
\hline 1 to10 & V & Very low \\
\hline 0.1 to 1 & IV & Imperceptible \\
\hline$<0.1$ & VI \\
\hline
\end{tabular}

The lithology and well design profile of the each well are illustrated in Figures 8, 9, 10,11 respecitevely:

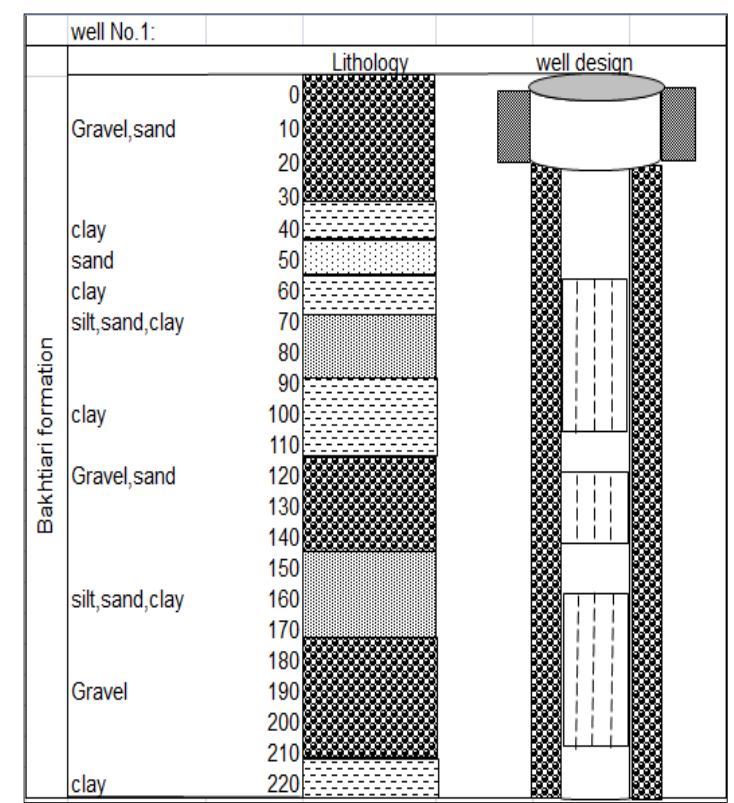

Fig.8 - Lithology of well No.1

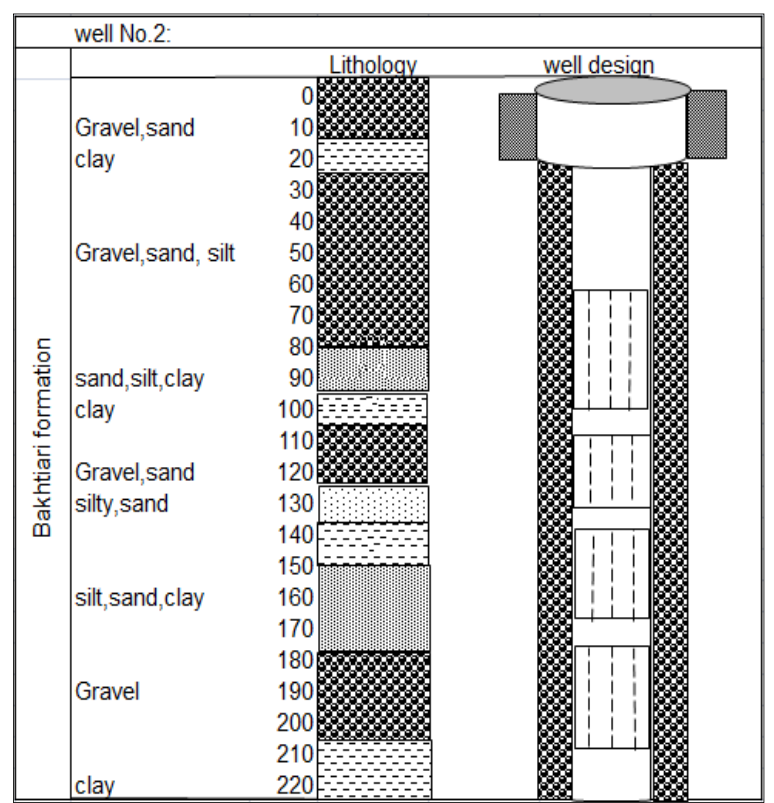

Fig.9 - Lithology of well No.2 


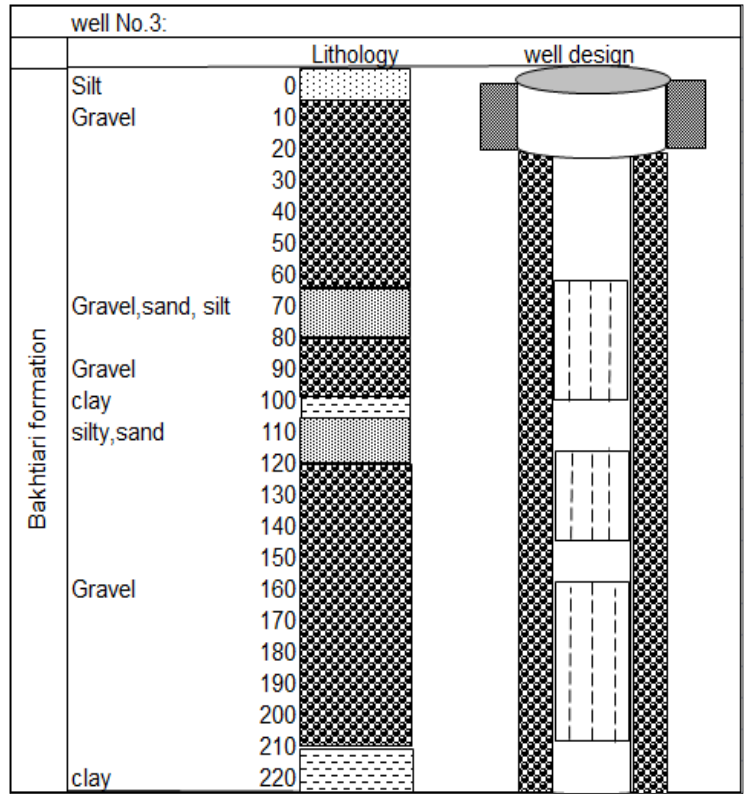

Fig.10 - Lithology of well No.3

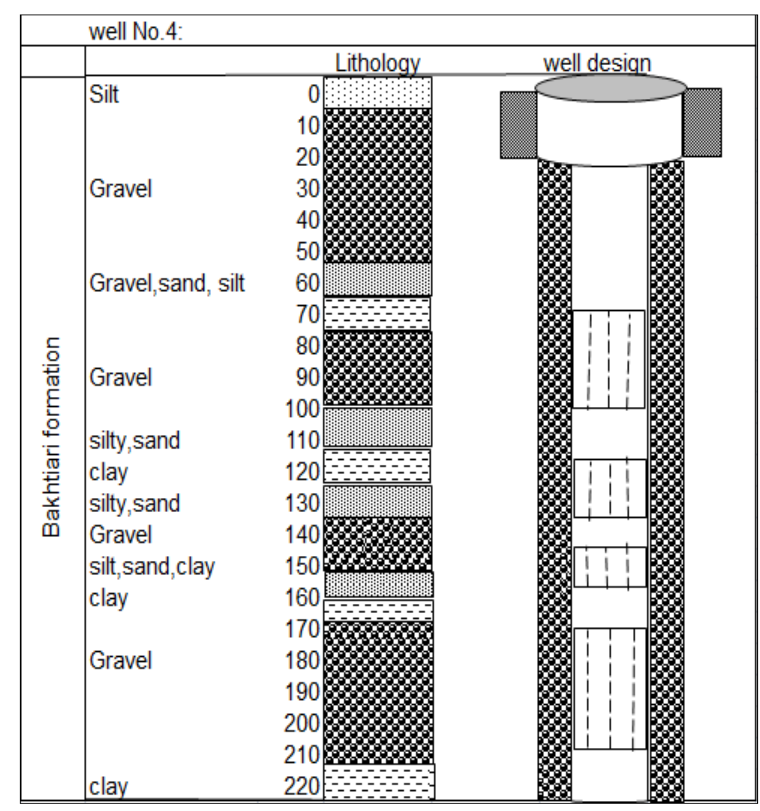

Fig.11 - Lithology of well No.4

\section{Conclusion}

According to the analysis of the test data, the results are satisfied that the value of storage coefficient is overestimate in case of single well test, due to well losses inside the production well,this leads to cause high drawdown on the plot of the straight line of time versus drawdown, see figures [3,6] in Appendix, and the radial distance in this case represented the radius of the well[ $\left.r_{w}\right]$, which is the screened part of the well, and that's why the value of the specific yield is out of the standard range,because according to[11],the value of storage coefficient for watertable aquifer type should be within [0.1 to 0.3],and the degree of the accuracy the value of Storativity depends on the radial distance from pumping well observation well, so that in this study tried to determining the two main reasons behind that,which will cause to obtained unreality value of Storativity or specific yield, however the Transmissivity is regardless the above two reasons of the Storativity, it can be estimated with or without observation well and that is all the aim of the research to present the main factors that affecting on estimating the value of the aquifer parameters, so it is recommended that in case of single well test it is better to first obtain the radial distance,the effective wellbore store radius should be introduced as a radius to imaginary monitoring well i timedrawdown analysis, it can be estimated through step-drawdown test or skin factor equation. A method should be developed to estimate the real effective well radius to obtain the reliable value of Storativity. The following are the explaination of the pumping well and radial distances during the pumping test, see Figure 12, appyling continuity equation.

$Q_{1}=Q_{2}$

$A_{1} V_{1}=A_{2} V_{2}$

$2 \pi R_{1} h_{1} V_{l}=2 \pi R_{2} h_{2} V_{2}$

$R_{1} V_{1}=R_{2} V_{2}$

$R_{2}>R_{1}$

$V_{1}>V_{2}$

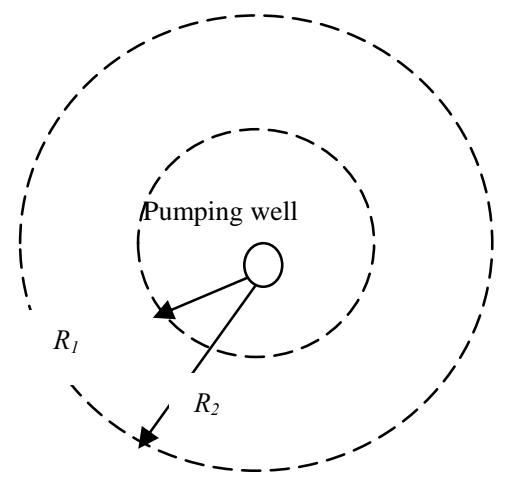

Fig 12 - Plan view of the imaginary well 
Notation:

$s$ - is drawdown $[m]$.

$Q$ - is constant rate pumping test $\left[\mathrm{m}^{3} \cdot \mathrm{sec}^{-1}\right]$

$T$ - is Transmissivity $\left[\mathrm{m}^{2} \cdot \mathrm{sec}^{-1}\right]$.

$S$ - is Storativity[unit less].

$r$ - is radial distance $[m]$.

$u$ - is well constant.

$W(u)$ - is well function.

$t$ - is time of pumping [ $\mathrm{sec}$ or $\mathrm{min}$ ].

$\Delta s$ - is slope of the line per one log cycle $[m]$

$t_{o}$-is the initial time of pumping test at zero drawdown [sec or min].

$\gamma$-is Euler number $=-0.5772$.

$h$ - is aquifer thickness $[m]$ in water-table aquifer.

$b$ - is the aquifer thickness for confined aquifer type $[m]$

$r_{w}$ - is radius of the well $[\mathrm{m}]$.

$r_{e}$ - is the effective radius of the well $[m]$

$s_{w}$ - is the drawdown at the well [ $m$ ]

$S c$ - is the specific capacity of the well $\left[\mathrm{m}^{3} \cdot \mathrm{s}^{-1}\right.$ per $m$ drawdown $]$

$Y$ - is linear equation

$B$ - is intercept of the line.

$C$ - is the slope of the line.

$x$ - is X-axis.

$s w l$ - static water level $[m]$

$d w l$ - dynamic water level $[m]$

$R_{1}, R_{2}$ - the radial distances from pumping well to observation well 1 and 2. [m]

$V_{1}, V_{2}$ - the velocity of the water of section 1 and 2. $[\mathrm{m} / \mathrm{s}]$

$h_{1}$ and $h_{2}$ the thickness of the aquifer @ $\mathrm{R}_{1}$ and $\mathrm{R}_{2}$ respectively $[m]$

\section{References}

[1] G.P. Kruseman, and N .A.de Ridder.(1991). Analysis and evaluation of pumping test data. 2nd edition, International institute for land reclamation and Improvement/ILRI, 11, 2000.

[2] P.N. Ballukraya and K.K. Sharma.(1991).Estimation of Storativity from Recovery Data.Groundwater.Vol.29,4.

[3] Choi, Byong-soo .(2007).A Method for Storativity Compensation in Single Well Test Analysis. Korean Journal of soil and groundwater environment . Vol. 12, 3.(pp. 36-43).

[4] Keith J.Halford,Willis D.Weight, and Robert P. Schreiber.(2006).Interpretation of Transmissivity Estimates from single well pumping aquifer test.Groundwater.Vol.44,3. (pp. 467-473). DOI:10.1111/j.17456584.2005.00151.x.

[5] Yaran M.Sternberg.(1970).Flow to wells in the presence of Radial Discontinuities.

[6] Roscoe moss company.(1990). Handbook of groundwater development, John Wiley and sons

[7] J. Boonstra and R.A.L .Kselik.(2001). STAEM 2002:software for Aquifer Test Evaluation.57, ILRI.

[8] Jacob, C. E.(1946). Drawdown test to determine effective radius of artesian well. Trans. Amer. Society Civil engrs. v.112,pp.1047-1070.

[9] Theis, C.V.(1963). Estimating the Transmissivity of a water-table aquifer from the specific capacity of a well. U. S., Geological survey water supply paper1536-I. pp.332-336.

[10] Brown, R. H.(1963). Estimating the Transmissivity of an artesian aquifer from the specific capacity of a well. U. S, Geological survey water supply paper 15336-I. pp. 336-338.

[11] Michael Kasenow.(2006). Aquifer Test Data: Analysis and Evaluation. Water resources publications.

[12] Aboufirassi, M. and M. A. Mari(1984). Cokriging of aquifer Transmissivity from field measurements of Transmissivity and specific capacity. Math. Geol. V. 16. No 1.pp.19-35. 
[13]M. Razack and David Huntley.(1991).Assessing Transmissivity from specific capacity in a large and Heterogeneous Alluvial Aquifer. Groundwater. V.29. 6.

[14] Willis D. Weight. (2008). Hydrogeology Field manual.2nd Edition, McGraw-Hill companied, 2001.

[15] Robert J. sterrett.(2007). Groundwater and wells. 3rd Edition. Johnson screen.

[16] I. Johnson.(1967). Specific Yield -Compilation of specific yields for various materials. united stated government printing office. Washington,

[17] Neven. Kresic.(2006). Hydrogeology and groundwater modeling.2nd edition, CRC Press.

[18]Hurr, R. T .(1966). A new approach for estimating Transmissivity from the specific capacity. Water Resources Research.V.2. 4. pp.657-664.

[19] Michael Kasenow.(1997). Introduction To Aquifer Analysis. 4th Edition. Water resources publications.

[20] S. W. LOHMAN.(1972).Groundwater Hydraulics. united states government printing office. Washington.

[21] Jonathan Peter Reed.(1997). Inverse Solution Techniques for Determining Aquifer Parameters from Pump Test Data. University of Durham.

[22] Djaouida Chenaf and Robert P. Chapures .(2002).Methods to Determine Storativity of Infinite Confined Aquifers from A Recovery Test. Groundwater. Vol.40, 4.

[23] C. W. Fetter.(1952). Applied Hydrology. 4th Edition. Prentice Hall.

[24] David K. Todd, and Larry W. Mays.(2000).Groundwater Hydrology. John Wiley\& Sons. 200.

[25] Kasenow, M. (2001). Applied Groundwater Hydrology and Well Hydraulics. Second Edition, Water Resources Publications, Highlands Ranch, Colorado.

[26] Bierschenk, William H.(1963). Determining well efficiency by multiple step-drawdown tests. International Association of Scientific Hydrology. 64:493-507.

[27] Hantush Mahdi S.(1964). Advances in Hydro science. chapter Hydraulics of Wells. pp 281-442. Academic Press.

[28] Rorabaugh. M.I. (1953). Graphical and theoretical analysis of step-drawdown test of artesian wells. Transactions, American Society of Civil Engineers. 79(separate 362).1-23

[29] Cooper. H.H. and Jacob. C.E.(1946) .A generalized graphical method for evaluating formation constants and summarizing well field history. American Geophysical Union

[30] Driscoll. F.G.(1986).Groundwater and wells . 2nd ed.: Transactions. V. 27, p. 526-534St. Paul. Minn. Johnson Filtration Systems. Inc. 1,089 p

[31] Batu. V. (1998). Aquifer Hydraulics: A Comprehensive Guide to Hydrogeologic Data Analysis. John Wiley \& Sons, New York.

[32] Ferris, J.G. (1959). Groundwater. In: C.O. Wisler and E.F. Brater (Editors), Hydrology. John Wiley and Sons. New York.

[33] Freeze. R.A. and Cherry. J.A. (1979). Groundwater. Prentice-Hall. New Jersey.

[34] Scott C.Alexander and Martin O.Saar.(2012).Improved Characterization of small " $u$ " for Jacob Pumping Test Analysis Methods.Groundwater.Vol.50,2. (pp. 256-265). DOI:10.1111/j.1745-6584.2011.00839.x.

[35] Imad Al-Din Omer Hassan.(1998). Urban Hydrology of Erbil City Region. Degree of doctor of philosophy in geology (hydrogeology).University of Baghdad

[36] Mariwan Akram Hama Saeed Chnaray.(2003).Hydrogeology and Hydrochemistry of Kapran Basin Erbil-N-of Iraq. Degree of Doctor of Philosophy in Geology. University of Baghdad

[37] Shwan Omer Ismail Shwani.(2008). Hydrogeology and Hydrochemistry of Bashtapa sub- Basin in Erbil Governorate Kurdistan Region - Iraq. Degree Of Master of Science in Geology. Salahaddin University

[38] Masoud Hussein Hamed.(2013). Hydrogeology, Hydrochemistry and Groundwater flow Modeling of Shaqlawa- Hiran Basin in Erbil Governorate Iraqi Kurdistan Region. Degree of Doctor of Philosophy in Geology. Salahaddin University

[39] Diary Ali Mohammad Ameen Al-Manmi.(2008).Water Resources Management in Rania Area Sulaimaniyah NE-Iraq. Degree of doctor of philosophy in geology (hydrogeology).University of Baghdad

[40] Dara Faeq Hamamin.(2004). Hydrogeological assessment and groundwater vulnerability map of basara basin,sulaimani governorate,iraqi kurdistan region. Degree of Doctor of Philosophy in Geology. University of Sulaimani

[41] Salahaddin Saeed Ali.(2007).Geology and Hydrogeology of Sharazoor Piramagroon Basin in Sulaimani Area, Northeastern Iraq. Degree of Doctorate of Philosophy in Faculty of Mining and Geology. University of Belgrade

[42] Jiri Krasny .(1993).Classification of Transmissivity Magnitude and Variation.Vol.31,No2-Groundwater. 